\section{Final Decision}

Sir,-When I read Professor McCrea's suggestion (Nature, 239, 239; 1972) for limiting scientific publication by a scheme to be called ACRE, I wondered whether he had intended it in satiric vein. $\mathrm{Dr}$ O'Connor's suggestion (Nature, 239, 418; 1972) of calling for support by postcard, before full publication is made, raises a number of serious objections.

Authors in big departments or with a wide circle of friends would doubtless tend to receive more support than others. It would set an extra hurdle in the path of the unorthodox. Authors in fields with few workers might not receive the necessary support in the popularity poll. It would surely accentuate the offering of inferior material to journals with less critical editors.

Over recent years, there has been a tendency, albeit with exceptions, towards shorter papers but it depends greatly on the topic whether argument should be in full and data briefly summarized, or the reverse.
Let us not put ourselves in an unnecessary straitjacket but leave it to editors to assess quality rather than quantity or popularity.

Yours faithfully,

\section{E. A. George}

Culture Centre of Algae and Protozoa, 38 Storey's Way, Cambridge CB3 ODT

\section{DDT and Peregrines}

SIR,--It would have been more enlightening if D. L. Gunn (Nature, 239, 296; 1972) had specified why the evidence I quoted (Nature, 238, 475; 1972), linking the decline of peregrine with the persistent pesticides, was unsound, or had submitted the evidence to the contrary. Instead he says, without quoting the specific references, that "the evidence was examined by the Wilson Committee ${ }^{1}$ and the Mrak Commission ${ }^{2}$ and found to be inadequate".
I commented earlier on his selective use of the Wilson Committee findings and he gives no reasons now for regarding as "not altogether convincing" their suggestion that dieldrin was responsible. The Mrak Commission dealt with the decline of peregrine and other species at some length and concluded (p. 212), "These experiments appear to forge the last link in the chain of evidence that DDT and its derivatives have been the direct and principal cause of widespread and significant reductions in bird populations".

\section{Yours faithfully,}

\section{Stanley Cramp}

32 Queen Court,

\section{London $W C 1 N 3 B B$}

1 Advistory Committee on Pesticides and other Toxic Chemicals, 148 (HMSO, 1969).

2 Report of the Secretary's Commission on Pesticides and their Relationship to Environmental Health, 677 (US Department of Health, Education and Welfare, 1969).

\title{
Obituary
}

\section{Professor Trevor Ian Shaw}

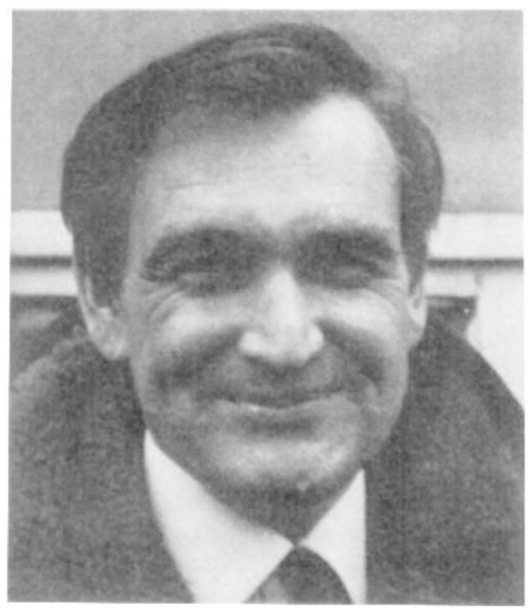

Trevor Shaw was born in 1928 and educated at Bootham School, York, and at Clare College, Cambridge, where he read the Natural Sciences Tripos and where he also studied parts one and two of the Bachelor of Medicine degree. After graduation in 1950 he remained at Cambridge on an MRC studentship to undertake research at the Physiological L.aboratory under the supervision of Sir Alan Hodgkin, PRS. On completing the work for his doctorate in 1953 he was called up for National Service and seconded to the Medical Division of the Chemical Defence Experimental Estab- lishment at Porton until his release from the army in 1955. For the next 11 years he worked at the Plymouth Laboratory of the Marine Biological Association of the United Kingdom, at first on a grant from the Atomic Energy Authority to study the uptake of fission products by marine organisms and then, from 1958 onwards, as a physiologist on the MBA staff. These years at Plymouth were both happy and productive and were marked by a succession of original discoveries which reflected his ability to deal with a number of fundamental problems in biology. In 1966 he was appointed Professor of Zoology in London University and spent the next six years at Queen Mary College. His warm and unassuming character, immense knowledge and infectious enthusiasm won him an ever widening group of appreciative undergraduates and colleagues. He was fully involved in his work up until his premature death on September 26, 1971.

Research work was a central part of Trevor Shaw's life and he was among the first to demonstrate, on red blood cells, a coupling between the transport of sodium and potassium ions. Later he elucidated the mechanism by which seaweeds accumulate iodine but above all he will be remembered for his sustained researches on the properties of nerve membranes. He was a brilliant experimentalist and devised, with $\mathrm{Dr}$ P. F. Baker, a remarkable method of perfusing the giant axon of the squid with artificial media. This allowed the complete control of the contents of an active nerve fibre, a facility which Shaw and Baker together with Sir Alan Hodgkin and other collaborators have brilliantly exploited during recent years.

This distinguished work on ion movements and energetics was only one of Trevor Shaw's many research activities. $\mathrm{He}$ was the first to show, with Dr F. Crescitelli, that the photosensitive visual pigments are circularly dichroic and that this dichroism disappears on bleaching the pigments. He also did very original work on the buoyancy of squid and gelatinous animals such as jellyfish and ctenophores. In the early months of this year he embarked on a new and promising line of research in which he exploited the peculiar properties of laser light to allow the detection of movements of subcellular particles in living nerve cells.

Throughout his research career Trevor Shaw collaborated with some of the most famous physiologists in the country. It was easy to see how these collaborations developed, for he had an insatiable interest in research and a tremendously cooperative approach throughout his whole life. He was a gifted theoretician and never happier than when calculating the exact implications of a ncw idea. It was typical of his intellectual energy that he should spend hours with an insurance agent 